\title{
Profil DNA Forensik pada Barang Bukti Dua Kasus Pembunuhan di Indonesia
}

\section{Forensics' DNA Profiling using Evidence from Two Crimes of Homicide in Indonesia}

\author{
PUJI RIANTI ${ }^{1 *}$, ELISA CRISTIN ${ }^{1}$, PUTUT TJAHJO WIDODO ${ }^{2}$

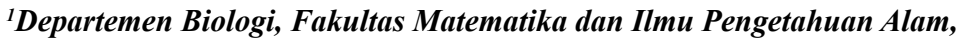 \\ Institut Pertanian Bogor, Kampus IPB Dramaga, Bogor 16680 \\ ${ }^{2}$ Laboratorium DNA Pusat Kedokteran dan Kesehatan, Kepolisian Negara Republik Indonesia, \\ Cipinang Baru Raya no. 3B, Jakarta Timur 13240
}

Diterima 18 Februari 2018/Disetujui 26 April 2018

\begin{abstract}
DNA technology for profiling purposes has been used in many basic and applied science. One of the emerged applied science in genetics is it's uses in solving crime cases. Homicide became one of highest crime cases in Indonesia. Solving its cases through DNA profiling technology using items of evidence as tool is needed. Here, we report the profiling of human DNA from several items of evidence available in the crime scene and the suspect. We used items of evidence from study cases no. 18098 and 18101, based on the legal permission of Indonesia's National Police. We used 21 international standards of human STR markers, one sex-determining marker, one Y STR marker, and one independent $Y$ marker to developed human alleles from tissue and blood stains left and/or shred on the victims, soap bottles, knifes, victim's clothes, and ropes as well as the buccal swab of the crime suspect. Our alleles identification matched between the victim and the crime suspect in both cases with the accuracy of DNA profiles compatibility at $\mathbf{9 9 . 9 9 \%}$. Detection of DNA profiling is depending on the evidence and time of storage which are influence by environment that can lead to the process of decayed and/or contaminated.
\end{abstract}

Key words: human STR markers, human tissues, blood stain

\section{PENDAHULUAN}

Identifikasi DNA terutama fungsinya sebagai alat bantu penyelesaian kasus kriminalitas di dunia telah berkembang dengan sangat pesat. Sidik jari DNA atau profil DNA dalam tindak kriminalitas pertama kali dilaporkan pada tahun 1988 dalam penyelesaian kasus pembunuhan berantai dua gadis remaja di Leicestershire, Inggris (Seton 1988). Terdapat dua jenis marka genetik yang secara umum digunakan dalam ilmu forensik yaitu DNA mitokondria dan DNA inti (Butler 2015). Namun sifat DNA mitokondria yang memiliki kelemahan hanya diturunkan dari garis keturunan ibu kurang tepat untuk digunakan dalam mendiskriminasikan profil DNA individu dibandingkan dengan DNA nukleus (diturunkan dari ayah dan ibu) (Budowle et al. 2003). Sehingga sejak tahun 1994, hampir seluruh profil DNA hanya menggunakan analisis lokus mikrosatelit DNA

*Penulis korespondensi: (+62251)8622833

E-mail: pujirianti@apps.ipb.ac.id nukleus yang kemudian dikembangkan ke dalam paket marka genetik mikrosatelit identifikasi manusia Globalfiler ${ }^{\circledR}$ (Sorensen et al. 2016). Lokus mikrosatelit yang dikembangkan sebagai profil DNA forensik tetap mengikuti hukum mendel dimana lokus-lokus tersebut diturunkan secara mandiri (tidak terkait genetik dan tidak berasosiasi dengan penyakit genetik) (Linacre dan Templeton 2014). Saat ini, profil DNA dipertimbangkan sebagai salah satu syarat utama dalam validasi penyelidikan dan tantangan jurisdiksi di pengadilan (Aronson 2008). Aplikasi penggunaan ilmu genetika forensik dalam mengevaluasi suatu barang bukti tindak kriminalitas menjadi sangat penting, tidak terkecuali dalam penyelesaian kasus kiminalitas, terutama kasus pembunuhan di Indonesia. Jumlah kasus pembunuhan yang ditangani oleh Kepolisian Republik Indonesia pada tahun 2017 mencapai 1.150 kasus (BPS 2018). Pada penelitian ini, kami melaporkan profil DNA forensik yang berasal dari materi biologis sampel barang bukti dua jenis kasus pembunuhan di Indonesia dengan menggunakan analisis paket marka genetik mikrosatelit identifikasi manusia Globalfiler ${ }^{\circledR}$ (Sorensen et al. 2016). 


\section{BAHAN DAN METODE}

Barang Bukti Kasus Pembunuhan. Sampel barang bukti yang kami gunakan dalam penelitian ini merupakan koleksi Laboratorium DNA Pusat Kedokteran dan Kesehatan, Kepolisian Negara Republik Indonesia (Pusdokkes POLRI). Barang bukti tersebut adalah barang bukti nomor 18098 dan 18101. Barang bukti nomor 18098 terdiri atas: jaringan tubuh yang melekat pada tulang paha korban (sampel nomor (SN): 18098_1), bercak darah pada botol sabun cair (SN: 18098_2), bercak darah pada botol pembersih lantai (SN: 18098_3), pisau dapur (SN: 18098_4), dan usapan pipi bagian dalam milik tersangka ( $\overline{\mathrm{SN}}$ : 18098 5). Selanjutnya, barang bukti nomor 18101 adalah pakaian milik korban (SN: 18101_1), tali merah (SN: 18101_2), tali hitam (SN: 18101_3), dan usapan pipi bagian dalam milik tersangka (SN: 18101_4).
Eksaminasi Materi Biologis. Sebelum eksaminasi dilakukan, areal meja kerja disterilisasi untuk menjamin tidak adanya kontaminasi dengan menggunakan campuran bleach $10 \%$ dan ethanol $70 \%$ (Kemp dan Smith 2005). Meja kerja kemudian dilapisi kertas alas yang dituliskan nomor kasus dan tanggal pemeriksaan barang bukti pada pojok kanan atas. Barang bukti kemudian diletakkan diatas kertas alas dan difoto untuk keperluan dokumentasi kegiatan. Sterilisasi meja dan penggantian kertas alas kerja dilakukan disetiap pelaksanaan eksaminasi materi biologi dari satu sampel untuk menghindari adanya kontaminasi silang antar sampel dari setiap barang bukti.

Eksaminasi Barang Bukti dari Lokasi Kejadian Perkara Nomor 18098 (Gambar 1). SN: 18098_1. Jaringan tulang dipotong sebanyak +0.1 gr untuk kemudian di masukkan ke dalam tabung sampel PrepFiler®.
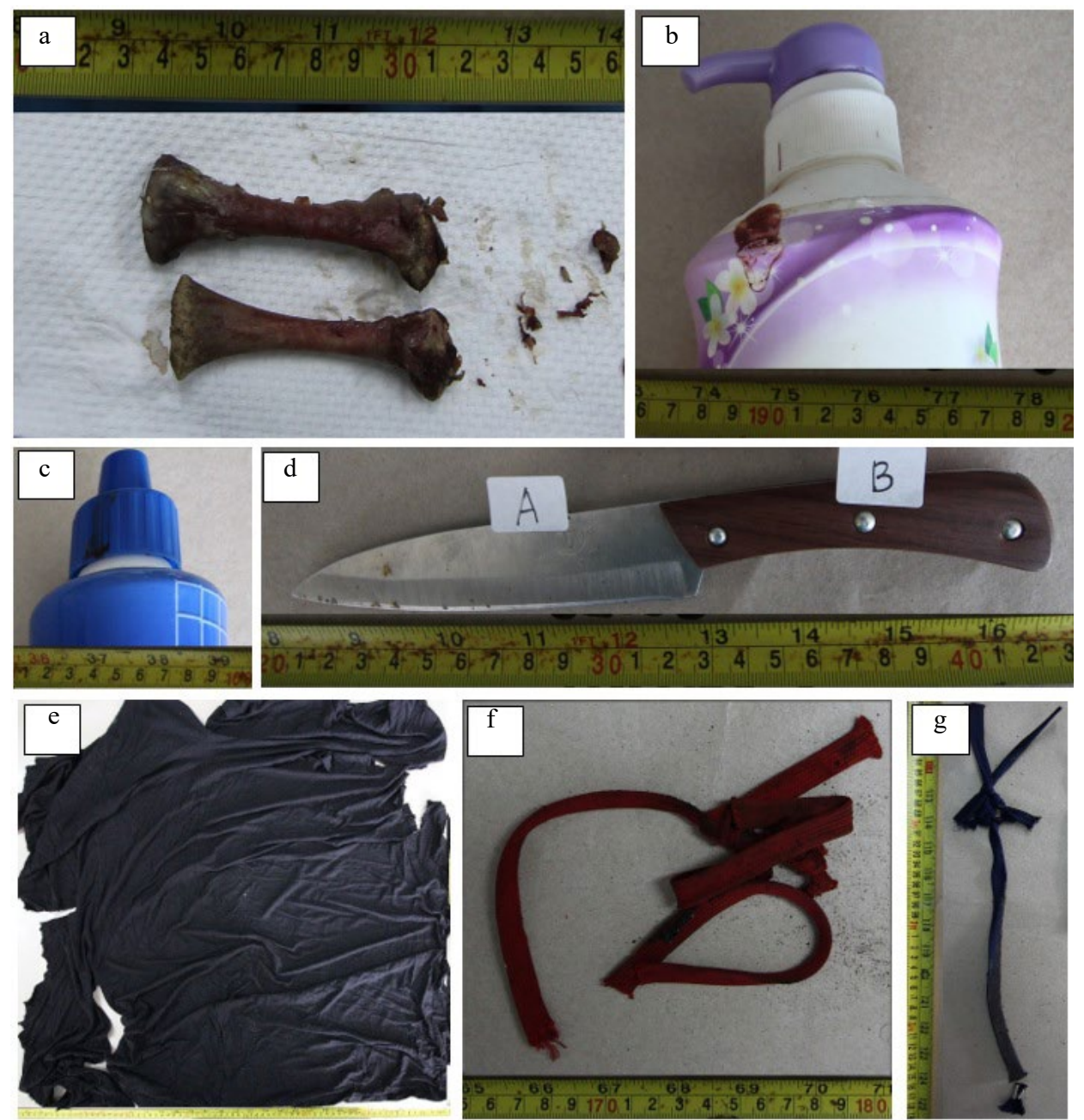

Gambar 1. Barang bukti kasus pembunuhan asal TKP nomor 19098 dan 18101. (a) Jaringan yang menempel pada tulang paha korban, (b) bercak darah pada botol sabun mandi, (c) bercak merah pada botol pembersih lantai, (d) pisau dapur yang diduga sebagai alat pembunuhan, (e) pakaian korban, (f) tali merah yang diduga sebagai alat bantu pembunuhan, (g) tali hitam yang diduga sebagai alat bantu pembunuhan 
SN: 18098_2. Permukaan botol sabun mandi yang terdapat beberapa bercak darah diusap dengan batang kapas usap yang telah dibasahi $\mathrm{ddH}_{2} \mathrm{O}$. Sampling dilakukan dari dua bercak darah yang berbeda. Bagian kapas usap dari batang kemudian dipotong dan dimasukkan ke dalam microtube safelock $2 \mathrm{ml}$ dan diberi kode SN: 18098_2a dan 18098_2b. Tabung sampel kemudian dicuci menggunakan $1 \mathrm{ml}$ TE buffer dan divorteks hingga homogen. Tabung sampel kemudian diinkubasi selama 1 jam pada suhu $56^{\circ} \mathrm{C}$. Selanjutnya tabung kembali divorteks dan disentrifugasi dengan Mikro 200R 13,000 rpm selama 3 menit. Supernatan hasil sentrifugasi dipindahkan ke dalam tabung sampel baru dan disimpan untuk metode selanjutnya.

$\mathrm{SN}$ : 18098_3. Botol pembersih lantai yang diduga terdapat bercak darah dilakukan uji o-Tolidine hidroklorida (Zwarenstein 1949; Cox 1991). Uji o-Tolidine hidroklorida dilakukan untuk memastikan bahwa bercak kering berwarna merah kecoklatan pada barang bukti adalah bercak darah. Bercak kering berwarna merah pada botol pembersih lantai diusap menggunakan batang kapas usap sebanyak lima kali. Kemudian kapas dengan bercak berwarna merah tersebut diteteskan cairan o-Tolidine dan $\mathrm{H}_{2} \mathrm{O}_{2}$. Apabila setelah 10 detik didapatkan warna biru pada kapas usap tersebut (Gambar 2), maka dipastikan bercak merah pada botol merupakan bercak darah. Selanjutnya bagian bercak merah pada botol yang telah di uji o-Tolidine dan dinyatakan sebagai bercak darah, di usap dengan menggunakan batang kapas usap steril baru dan dilakukan perlakuan seperti eksaminasi SN: 18098_2.

SN: 18098_4. Sampel barang bukti pisau dapur dieksaminasi pada dua bagian, yaitu: mata pisau (a) dan gagang pisau (b). Sampling pada seluruh permukaan mata pisau sebelah kiri dilakukan dengan menggunakan kapas usap yang dibahasi $\mathrm{ddH}_{2} \mathrm{O}$ dan diberi kode SN: 18098_4a1. Selanjutnya sampling pada seluruh permukaan mata pisau sebelah kanan dengan menggunakan kapas usap kering dan diberi kode SN: 18098_4a2. Sampling pada gagang pisau dilakukan dengan mengusap seluruh permukaan gagang pisau menggunakan kapas usap kering dan diberi kode SN: 18098_4b. Eksaminasi barang bukti ini mengikuti metode eksaminasi SN: 18098_2 dengan modifikasi tambahan sampel apusan kering pada bagian yang dimaksud.

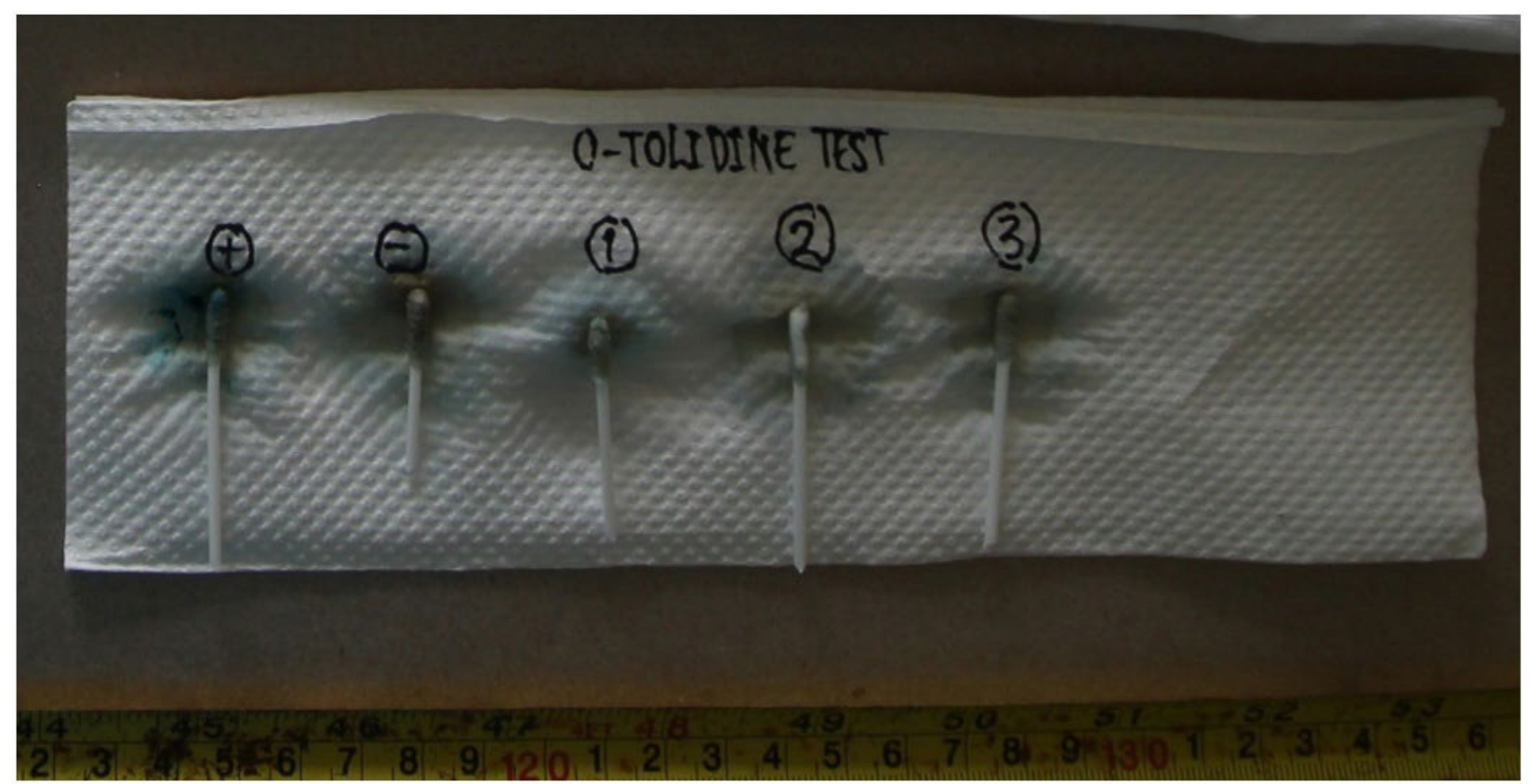

Gambar 2. Hasil uji o-Tolidine 
Eksaminasi Barang Bukti dari Lokasi Kejadian Perkara Nomor 18101 (Gambar 1). Seluruh permukaan pakaian milik korban (SN: 18101 1), tali merah (18101 2), dan tali hitam (18101_3) masing-masing dilakukan perlakuan apusan basah menggunakan batang kapas usap yang sudah dibasahi dengan $\mathrm{ddH}_{2} \mathrm{O}$ dan diapus kering bagian luar dan dalam pakaian. Selanjutnya metode eksaminasi mengikuti SN: 180982 . Eksaminasi sampel pakaian milik korban diberi kode SN: 18101_1a, 18101_1b, dan 18101_1c. Sampel tali merah dan hitam, berurutan diberi kode SN: 18101_2a, 18101_2b, 18101_3a, dan 18101_3b.

Eksaminasi Barang Bukti Tersangka Pembunuhan Nomor 18098 dan 18101. Batang kapas usap hasil apusan epitel pipi bagian dalam tersangka kasus nomor 18098 dan 18101 dikeluarkan dari selongsongnya. Kemudian bagian kapas dari dua kasus pembunuhan yang berbeda tersebut dipotong dan dimasukkan ke dalam dua microtube safelock $1.5 \mathrm{ml}$ yang terpisah. Tabung sampel dari masing-masing barang bukti tersangka diberi kode SN: 180985 dan 181014.

Ekstraksi DNA. Sampel diekstraksi mengikuti metode Chelex 5\% (Walsh et al. 2013) yang merupakan campuran 5 gr Chelex (Biorad, USA) di dalam $100 \mathrm{ml}$ larutan TE Buffer $\mathrm{pH}$ 8.0. Larutan TE Buffer merupakan campuran $0.61 \mathrm{~g}$ Tris Base (Sigma, USA) dan $0.0186 \mathrm{~g}$ EDTA (Sigma, USA)

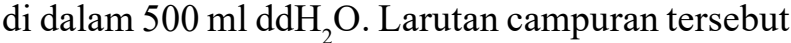
kemudian ditambahkan $\mathrm{HCl} 1 \mathrm{M}$ atau $\mathrm{NaOH} 1$ $\mathrm{M}$ hingga $\mathrm{pH}$ larutan mencapai 8.0. Sebelum digunakan, Chelex 5\% dihomogenkan agar tidak ada endapan pada larutan.

Sebanyak $400 \mu$ l Chelex 5\%, $2 \mu \mathrm{l}$ prot K $10 \mathrm{mg} /$ $\mathrm{ml}$, dan $18 \mu \mathrm{l}$ DTT $0.05 \mathrm{M}$ ditambahkan ke dalam tabung sampel dengan kode SN: 18098_1a dan 18098_1b. Kemudian tabung sampel diinkubasi di dalam waterbath shaking dengan suhu $56^{\circ} \mathrm{C}$ selama 4 jam. Tabung sampel dengan kode SN: 18098_2a, 18098 2b, 18098 3a, 18098 3b, 18098 4a1, $18098_{4 a 2}, 180984 \mathrm{~b} 1,18098^{-} 4 \mathrm{~b} 2,1809 \overline{8} 5 \mathrm{a}$, 18098_5b, 18101_1a, 18101_1b, 18101_2a, 18101_2b, 18101_3a, 18101_3b, 18101_4a, dan 18101_4b ditambahkan $400 \mu$ l Chelex $5 \%$ dan $10 \mu 1$ prot K $10 \mathrm{mg} / \mathrm{ml}$. Kemudian tabung sampel diinkubasi di dalam waterbath shaking dengan suhu $56^{\circ} \mathrm{C}$ selama 1 jam. Selanjutnya seluruh tabung sampel dikeluarkan dari waterbath dan dipanaskan selama 8 menit pada suhu $100^{\circ} \mathrm{C}$ menggunakan heating block. Masing-masing sampel kemudian di vorteks selama 10 detik dan di sentrifugasi pada 13,000 rpm selama 3 menit. Kemudian supernatan yang terbentuk di dalam tabung sampel dipindahkan ke dalam masing-masing tabung 1.5 $\mathrm{ml}$ yang baru dan disimpan pada suhu $4^{\circ} \mathrm{C}$ untuk analisis selanjutnya.

Kuantifikasi DNA. Sebanyak $10.5 \mu \mathrm{l}$ primer standar manusia, 12,5 $\mu$ l reaksi PCR (ABI Human Quantifiler kit; Applied Biosystem, USA), dan 2 $\mu$ sampel dimasukkan ke dalam plat 96 sumur (Applied biosystem, USA). Kemudian plat tersebut ditutup, di vortex, dan diputar pada kecepatan 3,000 rpm selama 1 menit. Kuantifikasi DNA dilakukan dengan memasukkan plat sampel ke dalam ABI 7,500 Real Time PCR (Applied Biosystem, USA).

Amplifikasi DNA. Sebanyak 21 marka penyandi mikrosatelit, satu marka penyandi kromosom-Y, satu marka indel-Y, dan satu marka penanda jenis kelamin (Amelogenin) yang tercampur dalam kit GlobalFiler ${ }^{\circledR}$ (Applied biosystem, USA) digunakan dalam meng-amplifikasi DNA sampel pada penelitian ini (Tabel 1). Reaksi yang digunakan adalah $7.5 \mu$ mater nix, $2.5 \mu \mathrm{l}$ pasang primer (forward dan reverse), dan $1 \mathrm{ng}$ sampel DNA hasil ekstraksi dimasukkan ke dalam tabung PCR. Kemudian tabung PCR yang telah terisi sampel tersebut dimasukkan ke dalam GeneAmp PCR System 9700 (Applied Biosystem, USA). Tahapan proses amplikasi di dalam mesin tersebut adalah: inisial pemanasan $95^{\circ} \mathrm{C}$ selama 1 menit; 96 siklus: denaturasi $94^{\circ} \mathrm{C}$ selama 10 detik, penempelan $59^{\circ} \mathrm{C}$ selama 90 detik, dan pemanjangan $60^{\circ}$ selama 10 menit, serta pemanjangan akhir $4^{\circ} \mathrm{C}$ selama 24 jam.

Mikrosatelit. Sebanyak $9.6 \mu \mathrm{l} \quad$ HiDi formamide, $0.4 \mu \mathrm{l} 600 \mathrm{LIZ}$ dan $1 \mu \mathrm{l}$ sampel hasil PCR dimasukkan ke dalam plat 96 sumur (applied biosystem, USA). Plat kemudian ditutup septa dan disentrifugasi pada 3,000 rpm selama 1 menit. Sampel dipanaskan pada suhu $95^{\circ} \mathrm{C}$ selama 3 menit dan diletakkan ke dalam freezer dengan suhu $-25^{\circ} \mathrm{C}$ selama 3 menit. Setelah itu sampel di analisis dengan menggunakan ABI 3500XL Genetic Analyzer (Applied Biosystem, USA).

Penentuan Genotipe. Data hasil dari pembacaan ABI 3500XL Genetic Analyzer (Applied Biosystem, USA) dianalisis menggunakan GeneMapper ${ }^{\circledR}$ ID-X Software v1.4 (Applied Biosystem, USA). 
Tabel 1. Marka penyandi genetik multiplex GlobalFiler® (Sorensen et al. 2016)

\begin{tabular}{|c|c|c|c|c|c|c|}
\hline No & Lokus & Posisi fisik & Lokasi & Kategori & Pengulangan (5'3') & Panjang alel \\
\hline 1 & D3S1358 & Kromosom 3 & $3 \mathrm{p} 21.31$ & Kompleks & TCTA & $6-26$ \\
\hline 2 & D16S539 & Kromosom 16 & 16Q24.1 & Tunggal & GATA & $4-17$ \\
\hline 3 & D8S1179 & Kromosom 8 & $8 \mathrm{q} 24.13$ & Kompleks & TCTA & $6-20$ \\
\hline 4 & D21S11 & Kromosm 21 & $21 \mathrm{q} 21.1$ & Kompleks & TCTA & $14-43,2$ \\
\hline 5 & D18S51 & Kromosom 18 & $18 \mathrm{q} 21.33$ & Tunggal & AGAA & $5,3-40$ \\
\hline 6 & D2S441 & Kromosom 2 & $2 \mathrm{p} 14$ & Kompleks & TCTA/TCAA & $8-17$ \\
\hline 7 & D19S433 & Kromosom 19 & $19 \mathrm{q} 12$ & Kompleks & AAGG & $5,2-20$ \\
\hline 8 & $\mathrm{D} 22 \mathrm{~S} 1045$ & Kromosom 22 & $22 \mathrm{q} 12.3$ & Tunggal & ATT & $7-20$ \\
\hline 9 & D5S818 & Kromosom 5 & $5 \mathrm{q} 23.2$ & Tunggal & AGAT & $4-29$ \\
\hline 10 & D13S317 & Kromosom 13 & $13 \mathrm{q} 31.1$ & Tunggal & TATC & $5-17$ \\
\hline 11 & D7S820 & Kromosom 7 & $7 \mathrm{q} 21.11$ & Tunggal & GATA & $5-16$ \\
\hline 12 & D10S1248 & Kromosom 10 & $10 \mathrm{q} 26.3$ & Tunggal & GGAA & $7-19$ \\
\hline 13 & D1S1656 & Kromosom 1 & $1 q 42$ & Kompleks & TAGA & $9-20,3$ \\
\hline 14 & D12S391 & Kromosom 12 & $12 \mathrm{p} 13.2$ & Kompleks & AGAT/AGAC & $13-27,2$ \\
\hline 15 & D2S1338 & Kromosom 2 & $2 q 35$ & Kompleks & TGCC/TTCC & $10-31$ \\
\hline 16 & vWa & Kromosom 12 & $12 \mathrm{p} 21.31$ & Kompleks & TCTA & $6-26$ \\
\hline 17 & CSF1PO & Kromosom 5 & $5 q 33.1$ & Tunggal & AGAT & $5-17$ \\
\hline 18 & TPOX & Kromosom 2 & $2 \mathrm{p} 25.3$ & Tunggal & AATG & $4-16$ \\
\hline 19 & TH01 & Kromosom 11 & $11 \mathrm{p} 15.5$ & Tunggal & TCAT & $3-14$ \\
\hline 20 & FGA & Kromosom 4 & $4 q 31.3$ & Kompleks & CTTT/TTCC & $12,2-51,2$ \\
\hline 21 & SE33 & Kromosom 6 & $6 \mathrm{q} 14$ & Kompleks & AAAG & $3-49$ \\
\hline 22 & DYS391 & Kromosom Y & Yq11.21 & Tunggal & TCTA & $7-13$ \\
\hline 23 & Y indel & Kromosom Y & Yq11.221 & Kompleks & TTCTC/- & 1 atau 2 \\
\hline 24 & Amelogenin & Kromosom $\mathrm{X}$ dan $\mathrm{Y}$ & $\mathrm{Xp} 22.1-22.3$ dan $\mathrm{Y}$ & - & - & - \\
\hline
\end{tabular}
penyandi jenis kelamin

\section{HASIL}

Hasil ekstraksi DNA dari barang bukti tempat kejadian perkara (TKP) menunjukkan tidak semua barang bukti memiliki DNA manusia (baik korban maupun tersangka). Konsentrasi DNA yang berhasil diekstraksi dari barang bukti TKP cukup bervariasi, sedangkan barang bukti yang berasal dari ulasan epitel pipi bagian dalam tersangka mencapai $2.78 \mathrm{ng} / \mu \mathrm{l}$ untuk kedua kasus pembunuhan yang dilaporkan pada penelitian ini (Tabel 2).

Pada kasus pembunuhan nomor 18098, hasil analisis profil DNA dari barang bukti TKP menunjukkan adanya alel yang berasal dari dua individu yang berbeda (Tabel 3). Marka genetik kromosom Y, indel-Y, dan Amelogenin, juga menunjukkan adanya dua jenis kelamin (lakilaki dan perempuan) yang terlibat dalam kasus ini, dimana salah satunya sama dengan alel jenis kelamin tersangka. Tidak ada DNA yang dapat diamplifikasi dari barang bukti SN: 18098_3.

Sampel barang bukti kasus pembunuhan nomor 18101 menunjukkan hasil profil DNA yang lebih beragam dari barang bukti SN: 18098 (Tabel 4). Tidak seluruh marka genetik Globalfiler ${ }^{\circledR}$ dapat mengamplifikasi sampel barang bukti yang tersedia, misalnya pada alel D18S51, D13S317,
Tabel 2. Hasil ekstraksi DNA barang bukti TKP dan tersangka pada dua kasus pembunuhan nomor 18098 dan 18101

\begin{tabular}{|c|c|}
\hline Sampel & Konserntrasi DNA (ng/ $\mu \mathrm{l})$ \\
\hline $18098 \_1$ & 0.28 \\
\hline $180982 \mathrm{a}$ & 0.98 \\
\hline $18098 \_2 b$ & 0.07 \\
\hline $18098 \_3$ & 0.00 \\
\hline $180984 \mathrm{a} 1$ & 1.07 \\
\hline $18098 \_4 a 2$ & 0.02 \\
\hline $18098 \_4 b$ & 0.78 \\
\hline 180985 & 2.78 \\
\hline 18101_1a & 0.01 \\
\hline $18101 \_1 b$ & 0.00 \\
\hline $181011 \mathrm{c}$ & 0.19 \\
\hline $18101 \_2 a$ & 0.00 \\
\hline $18101 \_2 b$ & 0.00 \\
\hline $18101 \_3 a$ & 0.02 \\
\hline $18101 \_3 b$ & 0.05 \\
\hline 181014 & 2.78 \\
\hline
\end{tabular}

D1S1656, CSF1PO, TPOX, dan SE33. Walaupun demikian, marka genetik kromosom Y, indel-Y, dan Amelogenin menunjukkan adanya dua jenis kelamin yang berbeda pada sampel barang bukti asal TKP, yang mana salah satunya sama dengan alel jenis kelamin tersangka. Nilai akurasi kesamaan profil DNA korban dan tersangka pada sampel material biologis yang ditemukan di barang bukti asal TKP mencapai $99.99 \%$ untuk masing-masing kasus pembunuhan nomor 18098 dan 18101. 
Tabel 3. Profil DNA dari sampel barang bukti kasus pembunuhan nomor 18098

\begin{tabular}{|c|c|c|c|c|c|c|c|c|c|c|c|c|c|c|c|c|}
\hline \multirow{3}{*}{$\frac{\text { No. sampel }}{18098 \_1}$} & \multicolumn{16}{|c|}{ Marka genetik (alel) } \\
\hline & \multicolumn{2}{|c|}{ D3S1358 } & \multicolumn{3}{|c|}{ D16S539 } & \multicolumn{3}{|c|}{ D8S1179 } & \multicolumn{2}{|c|}{ D21S11 } & \multicolumn{3}{|c|}{ D18S51 } & \multicolumn{3}{|c|}{ D2S441 } \\
\hline & 15 & 16 & - & & - & 15 & - & 17 & 29 & 32.2 & - & 13 & 14 & 11,3 & 12 & - \\
\hline $180982 \mathrm{a}$ & 15 & 15 & 9 & 12 & 13 & 15 & 16 & 17 & 29 & 32.2 & 12 & 13 & 14 & 11,3 & & 14 \\
\hline 18098_2b & 15 & 16 & 9 & & 13 & 15 & & 17 & 29 & 32.2 & - & 13 & 14 & 11,3 & 12 & - \\
\hline $18098 \_3$ & - & - & - & - & - & - & - & - & - & - & - & - & - & - & - & - \\
\hline $180984 \mathrm{a} 1$ & 15 & 16 & 9 & 12 & 13 & 15 & 16 & 17 & 29 & 32.2 & 12 & 13 & 14 & 11,3 & & 14 \\
\hline 18098_4a2 & 15 & 16 & 9 & 12 & 13 & 15 & 16 & 17 & 29 & 32.2 & 12 & 13 & 14 & 11,3 & 12 & 14 \\
\hline $18098 \_4 b$ & 15 & 15 & - & 12 & 13 & - & 16 & 17 & 29 & 32.2 & 12 & 13 & - & 11,3 & - & 14 \\
\hline $18098 \_5$ & 15 & 15 & - & 12 & 13 & - & 16 & 17 & 29 & 32.2 & 12 & 13 & - & 11,3 & - & 14 \\
\hline
\end{tabular}

\begin{tabular}{|c|c|c|c|c|c|c|c|c|c|c|c|c|c|c|}
\hline \multirow{3}{*}{$\frac{\text { No. sampel }}{18098 \_1}$} & \multicolumn{14}{|c|}{ Marka genetik (alel) } \\
\hline & \multicolumn{3}{|c|}{ D19S433 } & \multicolumn{3}{|c|}{ D22S1045 } & \multicolumn{2}{|c|}{ D5S818 } & \multirow{2}{*}{$\frac{\mathrm{D} 13 \mathrm{~S} 317}{-}$} & \multicolumn{3}{|c|}{ D1S1656 } & \multicolumn{2}{|c|}{ D12S391 } \\
\hline & - & 14 & 16 & 11 & & 17 & 10 & 12 & & 11 & 14 & - & 19 & - \\
\hline $18098 \_2 \mathrm{a}$ & 13 & 14 & 16 & 11 & 16 & 17 & 10 & 12 & - & 11 & 14 & 15 & 19 & 20 \\
\hline 18098_2b & - & 14 & 16 & 11 & & 17 & 10 & 12 & - & 11 & 14 & - & 19 & - \\
\hline 180983 & - & - & - & - & - & - & - & - & - & - & - & - & - & - \\
\hline $180984 \mathrm{a} 1$ & 13 & 14 & 16 & 11 & 16 & 17 & 10 & 12 & - & 11 & 14 & 15 & 19 & 20 \\
\hline $18098 \_4 a 2$ & 13 & 14 & 16 & 11 & 16 & 17 & 10 & 12 & - & 11 & 14 & 15 & 19 & 20 \\
\hline $18098 \_\mathrm{b}$ & 13 & 14 & - & - & 16 & 17 & 10 & 12 & - & - & 14 & 15 & 19 & 20 \\
\hline $18098 \_5$ & 13 & 14 & - & - & 16 & 17 & 10 & 12 & - & - & 14 & 15 & 19 & 20 \\
\hline
\end{tabular}

\begin{tabular}{|c|c|c|c|c|c|c|c|c|c|c|c|}
\hline \multirow{3}{*}{$\frac{\text { No. sampel }}{18098 \_1}$} & \multicolumn{11}{|c|}{ Marka genetik (alel) } \\
\hline & \multicolumn{3}{|c|}{ D2S1338 } & \multicolumn{2}{|c|}{ vWa } & \multirow{2}{*}{ CSF1PO } & \multicolumn{2}{|c|}{ TPOX } & \multicolumn{3}{|c|}{ TH01 } \\
\hline & - & - & - & 14 & 16 & & - & - & 7 & 9 & - \\
\hline $18098 \_2 \mathrm{a}$ & 17 & 23 & 24 & 14 & - & $11 \quad 12$ & 9 & 12 & 7 & 9 & 10 \\
\hline $18098 \quad 2 b$ & 17 & 23 & & 14 & 16 & $11 \quad 12$ & 9 & 12 & 7 & 9 & - \\
\hline $18098 \_3$ & - & - & - & & - & & - & - & - & - & - \\
\hline $18098 \_4 a 1$ & 17 & 23 & 24 & 14 & 16 & $11 \quad 12$ & 9 & 12 & 7 & 9 & 10 \\
\hline $180984 \mathrm{a} 2$ & 17 & 23 & 24 & 14 & 16 & $11 \quad 12$ & 9 & 12 & 7 & 9 & 10 \\
\hline $18098 \_4 b$ & - & 23 & 24 & 14 & - & $11 \quad 12$ & 9 & 12 & 7 & - & 10 \\
\hline 180985 & - & 23 & 24 & 14 & - & $11 \quad 12$ & 9 & 12 & 7 & - & 10 \\
\hline
\end{tabular}

\begin{tabular}{|c|c|c|c|c|c|c|c|c|}
\hline \multirow{3}{*}{$\frac{\text { No. sampel }}{18098 \_1}$} & \multicolumn{8}{|c|}{ Marka genetik (alel) } \\
\hline & FGA & \multicolumn{3}{|c|}{ SE33 } & \multirow{2}{*}{$\frac{\text { DYS391 }}{-}$} & \multirow{2}{*}{$\frac{\mathrm{Y} \text { indel }}{2}$} & \multicolumn{2}{|c|}{ Amelogenin } \\
\hline & 2526 & - & - & - & & & $\mathrm{X}$ & $\mathrm{Y}$ \\
\hline $18098 \_2 \mathrm{a}$ & 212526 & 22.2 & 27.2 & 28.2 & 11 & 2 & $\mathrm{X}$ & $\mathrm{Y}$ \\
\hline $18098 \_2 b$ & 2526 & 22.2 & 27.2 & & 11 & 2 & $\mathrm{X}$ & $\mathrm{Y}$ \\
\hline $18098 \_3$ & $-\quad-\quad-$ & - & - & - & - & - & - & - \\
\hline $18098 \_4 a 1$ & 212526 & 22.2 & 27.2 & 28.2 & 11 & 2 & $\mathrm{X}$ & $\mathrm{Y}$ \\
\hline $18098 \_4 a 2$ & 212526 & & 27.2 & 28.2 & 11 & 2 & $\mathrm{X}$ & $\mathrm{Y}$ \\
\hline $18098 \_4 b$ & $21 \quad 26$ & & 27.2 & 28.2 & - & - & $\mathrm{X}$ & $X$ \\
\hline $18098 \_5$ & 2526 & & 27.2 & 28.2 & - & - & $\mathrm{X}$ & $\mathrm{X}$ \\
\hline
\end{tabular}

\section{PEMBAHASAN}

Hasil profil DNA forensik dari barang bukti dua kasus pembunuhan di Indonesia yang bernomor 18098 dan 18101 memberikan hasil yang berkorelasi positif antara sampel yang didapatkan pada barang bukti yang berasal dari tempat kejadian perkara (TKP) dan sampel tersangka. Hal ini membuktikan bahwa analisis profil DNA forensik di Indonesia dapat digunakan sebagai salah satu alat bantu penyelesaian kasus-kasus kriminalitas yang ada. Walaupun begitu, analisis profil DNA forensik sangat bergantung pada kualitas materi biologis yang didapatkan dari barang bukti di lokasi kejadian perkara maupun barang bukti lainnya yang berhasil dikumpulkan oleh penyidik di kepolisian (Mahajan et al. 2016). Cara penyimpanan barang bukti juga mempengaruhi kualitas materi biologis korban maupun tersangka yang tertinggal agar kontaminasi dapat dihindari (Pickrahn et al. 2017), sehingga analisis profil DNA harus segera dilakukan setelah barang bukti tiba di laboratorium.

Umumnya materi biologis yang tertinggal pada barang bukti asal TKP bukan merupakan materi biologis utuh (Mahajan et al. 2016). Pada kasus pembunuhan nomor 18098, kami mendapatkan koleksi sisa jaringan pada tulang korban serta bercak darah. Namun jaringan tubuh korban telah mengalami pembusukan dan bercak darah telah mengering sehingga material biologis 
Tabel 4. Profil DNA dari sampel barang bukti kasus pembunuhan nomor 18101

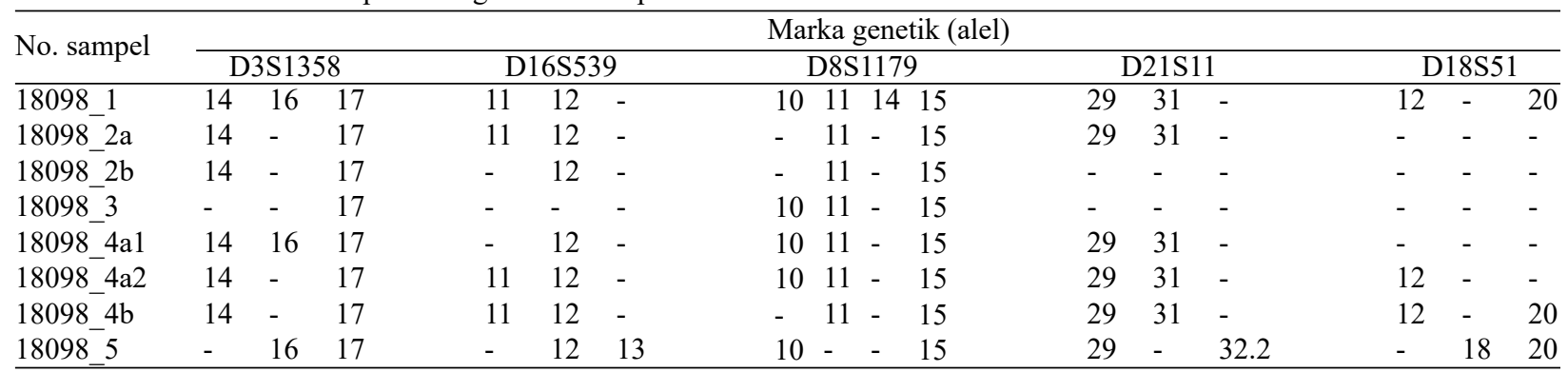

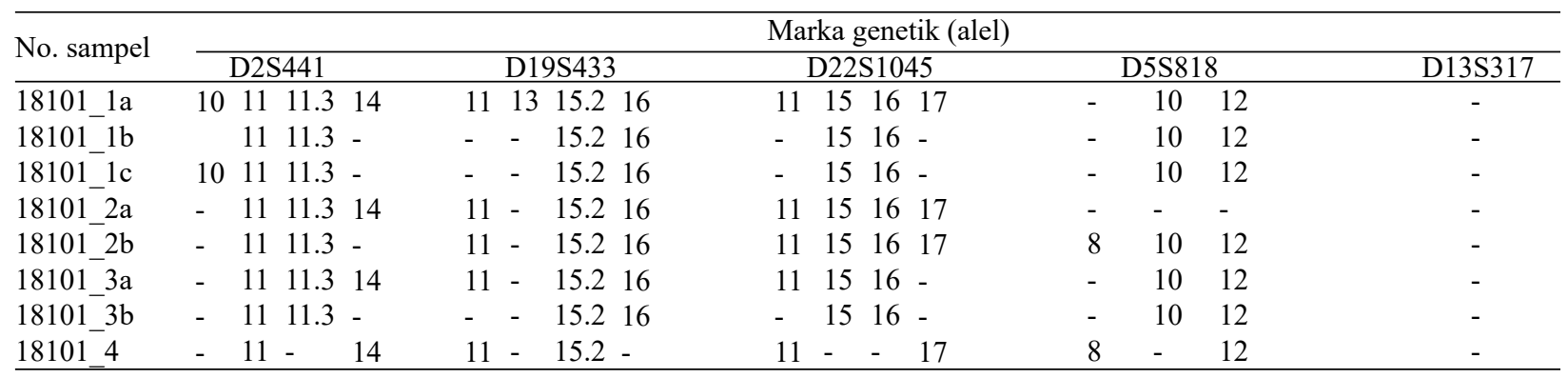

\begin{tabular}{|c|c|c|c|c|c|c|c|c|c|c|c|c|c|c|}
\hline \multirow{3}{*}{$\frac{\text { No. sampel }}{18101 \text { 1a }}$} & \multicolumn{14}{|c|}{ Marka genetik (alel) } \\
\hline & \multicolumn{3}{|c|}{ D1S1656 } & \multicolumn{3}{|c|}{ D12S391 } & \multicolumn{3}{|c|}{ D2S1338 } & \multicolumn{2}{|c|}{$\mathrm{vWa}$} & \multicolumn{3}{|c|}{ CSF1PO } \\
\hline & 15 & $16-$ & 17 & 19 & 20 & 24 & 17 & 21 & 24 & & 17 & 10 & - & - \\
\hline $18101_{-}^{-} 1 \mathrm{~b}$ & 15 & $-\quad-$ & 17 & & 20 & 24 & - & 21 & 24 & 14 & 17 & 10 & - & 12 \\
\hline 18101_1c & 15 & $-\quad-$ & 17 & - & - & - & - & - & - & 14 & 17 & - & - & - \\
\hline 18101_2a & - & - & - & - & - & - & - & - & - & - & - & - & - & - \\
\hline $18101 \_2 b$ & 15 & $-\quad-$ & 17 & - & - & - & - & - & - & 14 & 17 & - & - & - \\
\hline $18101 \_3 a$ & 15 & $-\quad-$ & 17 & - & 20 & 24 & - & 21 & 24 & 14 & 17 & - & - & - \\
\hline $18101 \_3 b$ & 15 & $-\quad-$ & 17 & - & 20 & 24 & - & 21 & 24 & 14 & 17 & 10 & & 12 \\
\hline $18101^{-} 4$ & - & 1616.3 & - & 19 & 20 & - & 17 & - & - & 14 & 17 & - & 11 & - \\
\hline
\end{tabular}

\begin{tabular}{|c|c|c|c|c|c|c|c|c|c|c|c|c|c|c|c|c|c|}
\hline \multirow{3}{*}{$\frac{\text { No. sampel }}{18101 \_1 \mathrm{a}}$} & \multicolumn{17}{|c|}{ Marka genetik (alel) } \\
\hline & \multicolumn{3}{|c|}{ TPOX } & \multicolumn{4}{|c|}{ TH01 } & \multicolumn{3}{|c|}{ FGA } & \multicolumn{3}{|c|}{ SE33 } & \multirow{2}{*}{$\frac{\text { DYS391 }}{10}$} & Y indel & \multicolumn{2}{|c|}{ Amelogenir } \\
\hline & 8 & - & 11 & 6 & - & 7 & 9 & 19 & 20 & 24 & - & 21.2 & 30.2 & & -2 & $\mathrm{X}$ & $\mathrm{Y}$ \\
\hline 18101_1b & 8 & - & 11 & - & - & 7 & - & 19 & 20 & - & - & - & - & - & - & $X$ & $\mathrm{X}$ \\
\hline $18101-1 \mathrm{c}$ & - & - & - & - & - & 7 & - & 19 & 20 & - & - & - & - & - & 1 & $\mathrm{X}$ & $\mathrm{Y}$ \\
\hline $18101 \_2 a$ & - & - & - & 6 & - & 7 & 9 & 19 & 20 & 24 & - & - & - & - & 1 & $\mathrm{X}$ & $\mathrm{Y}$ \\
\hline 18101_2b & - & - & - & 6 & 6.3 & 7 & 9 & 19 & 20 & 24 & - & 21.2 & - & - & 2 & $\mathrm{X}$ & $\mathrm{Y}$ \\
\hline $18101 \_3 a$ & 8 & - & - & 6 & 6.3 & 7 & - & 19 & 20 & 24 & - & - & - & - & 2 & $X$ & $\mathrm{Y}$ \\
\hline 18101_3b & 8 & - & 11 & - & - & 7 & - & 19 & 20 & - & - & - & - & - & - & $\mathrm{X}$ & $\mathrm{X}$ \\
\hline $18101 \_4$ & 8 & 9 & - & 6 & - & - & 9 & - & - & 24 & 18 & - & - & 10 & 2 & $X$ & $\mathrm{Y}$ \\
\hline
\end{tabular}

yang terkandung dipastikan telah mengalami degradasi ( Mahajan et al. 2016). Sedangkan pada kasus pembunuhan nomor 18101, kami hanya mendapatkan baju milik korban dan dua utas tali yang diduga merupakan alat atau media terjadinya perkara. Dari ketiga barang bukti tersebut, diharapkan masih tersisa material biologis (sisasisa jaringan epitel) yang tertinggal (Quinones dan Daniel 2012). Dalam menentukan pelaku tindak kriminal, selain barang bukti asal TKP, kami juga menggunakan material biologis berupa jaringan epitel hasil usapan pipi bagian dalam tersangka. Hal ini digunakan sebagai pembanding profil DNA material biologis barang bukti antara korban dan tersangka (Mcewen dan Regoeczi 2015).
Kuantitas ekstraksi DNA dari beragam barang bukti tindak kriminalitas yang kami ujikan pada penelitian ini menunjukkan adanya material biologis yang terdegradasi pada barang bukti $(<2$ ng; Tabel 2). Hal ini dikarenakan material biologis DNA (terkandung di dalam jaringan epitel, darah, atau ikat) yang tertinggal pada barang bukti sangat mudah terdegradasi di kondisi lingkungan yang tidak mendukung (Alaeddini et al. 2010). Kondisi lingkungan tidak mendukung yang dimaksud, terutama di daerah tropis seperti Indonesia, dapat berupa paparan panas tinggi, kelembaban tinggi, dan hidupnya bakteri maupun tumbuhnya cendawan. Meskipun demikian, jumlah DNA yang rendah dari masing-masing barang bukti asal TKP masih dapat 
dianalisis dalam menentukan profil DNA pemilik sampel (Budowle et al. 2009).

Kami melakukan analisis profil DNA dengan ketentuan yang telah distandarisasi oleh Federal Bureau of Investigation (FBI, USA) dengan menggunakan paket marka genetik GlobalFiler ${ }^{\circledR}$ (Aronson 2008; Flores et al. 2014). Penelitian ini menunjukkan bahwa standarisasi dan paket marka genetik tersebut dapat digunakan untuk keperluan forensik profil DNA dari material biologis terdegradasi asal barang bukti tindak kriminal di Indonesia. Pada kasus pembunuhan nomor 18098 (Tabel 3), satu sampel barang bukti (SN: 18098_3) tidak menunjukkan adanya profil DNA, diduga karena materi biologis pada barang bukti tersebut telah rusak atau terdegradasi ( Mahajan et al. 2016). Sampel SN: 18098_2a, 18098_4a1 dan 18098_4a2 menghasilkan campuran profil DNA yang berasal dari dua individu berbeda. alel indel-Y dan amelogenin menunjukkan adanya beda jenis kelamin antara sampel milik korban (barang bukti SN: 18098 1) dan sampel milik tersangka (barang bukti SN: 18098 5). Profil DNA SN: 18098 2b identik dengan profil DNA SN: 18098 1, sehingga terbukti bahwa profil DNA pada bercak darah pada botol sabun mandi sama dengan profil DNA dari jaringan yang melekat pada tulang paha korban. Selanjutnya, profil DNA SN: 18098_4b identik dengan profil DNA SN: 18098_5, yang artinya profil DNA pada gagang pisau merupakan profil DNA tersangka. Sebagian profil DNA SN: 18098_2a, 18098_4a1, dan 18098_4a2 mirip dengan sebagian profil DNA SN: 18098_1, sehingga dapat diartikan bahwa profil DNA dari mata pisau sisi kiri dan kanan serta bercak darah pada botol sabun mandi cair berasal dari DNA jaringan yang melekat pada tulang paha korban. Selain itu, sebagian lain dari profil DNA SN: 18098_2a, 18098_4a1, dan 18098_4a2 juga mirip dengan sebagian profil DNA SN: 18098_1, sehingga dapat diartikan bahwa sebagian profil DNA dari mata pisau sisi kiri dan kanan serta bercak darah pada botol sabun mandi cair juga berasal dari DNA tersangka. Selanjutnya dapat dilihat juga bahwa separuh profil DNA SN: 18098_1 identik dengan separuh profil DNA SN: 18098_5, sehingga dapat disimpulkan bahwa jaringan yang melekat pada tulang paha korban adalah anak biologis dari tersangka. Dengan demikian profil DNA pada barang bukti kasus pembunuhan nomor 18098 dapat membuktikan adanya keterlibatan tersangka pada tindak kriminal tersebut (Jobli dan Gill 2004; Kayser 2015).

Pada kasus pembunuhan nomor 18101 (Tabel 4), profil DNA dari masing-masing sampel barang bukti menunjukkan adanya degradasi material biologis yang lebih besar dari sampel barang bukti kasus nomor 18098. Profil DNA SN: 18101_2a dan 18101_2b menunjukkan bahwa material tali merah hanya memiliki sedikit material biologis yang terdegradasi. Sampel SN: 18101_1a, 18101_1c, 18101_2a, 18101_2b, dan 18101_3a menghasilkan campuran profil DNA yang mengindikasikan adanya material genetik yang berasal dari beberapa individu pada sampel tersebut. Marka genetik amelogenin menunjukkan adanya beda jenis kelamin antara SN: 18101_3b dengan SN: 18101_4, sehingga sampel tali hitam mengandung profil DNA perempuan yang diduga adalah milik korban dan sampel milik tersangka yang adalah laki-laki. Sebagian profil DNA pada SN: 18101_1a, 18101_1c, 18101_2a, 18101_2b, dan 18101_3a, mirip dengan sebagian profil DNA SN: 18101_4, yang artinya kaos hitam I korban, dan sampel tali merah dan tali hitam dibawah westafel kamar mandi sebagian berasal dari profil DNA tersangka. Selanjutnya, profil DNA SN: 18101_1b identik dengan profil DNA SN: 18101_2b, sehingga dapat dikatakan bahwa barang bukti berupa kaos hitam I korban samping closet kamar mandi sama dengan profil DNA pada sampel tali merah dan hitam. Walaupun sampel kasus pembunuhan nomor 198101 menunjukkan banyaknya sampel yang telah terdegradasi, namun pada sampel yang menunjukkan keragaman alelnya dapat menunjukkan adanya kecocokan antara sampel-sampel barang bukti TKP dengan sampel yang berasal dari korban maupun tersangka.

Secara umum profil DNA telah merevolusi proses identifikasi forensik pada manusia. Profil DNA merupakan salah satu metode yang digunakan dalam mengidentifikasi material biologis yang tertinggal pada barang bukti maupun sampel milik korban dan tersangka tindak kriminal (Linacre dan Templeton 2014; Mahajan et al. 2016). Proses pencocokan profil DNA saat ini sangat membantu para penyidik di kepolisian untuk mendapatkan bukti sahih keterlibatan seseorang dalam tindak kriminalitas, sehingga dapat digunakan sebagai salah satu analisis hukum (Kayser 2015; Linacre dan Templeton 2014).

\section{UCAPAN TERIMA KASIH}

Penulis mengucapkan terima kasih kepada seluruh tim Laboratorium DNA Pusdokkes POLRI yang telah bekerjasama, mengoleksi, dan mengijinkan penggunaan sampel barang bukti SN: 18098 dan 18101 pada penelitian ini. 


\section{DAFTAR PUSTAKA}

Alaeddini R, Walsh SJ, Abbas A. 2010. Forensic science international:genetics forensic implications of genetic analyses from degraded DNA-a review. Forensic Sci Int Genet 4:148-157.

Aronson JD. 2008. Creating the network and the actors: the FBI's role in the standardization of forensic DNA profiling. Biosocieties 3:195-215.

[BPS] Badan Pusat Statistik. 2018. Statistik Kriminal 2018. Jakarta:BPS.

Budowle B, Allard MW, Wilson MR, Chakraborty R. 2003. Forensics and mitochondrial DNA:applications, debates, and foundations. Annu Rev Genomics Hum Genet 4:119141.

Budowle B, Eisenberg AJ, van Daal A. 2009. Validity of low copy number typing and applications to forensic science. Croat Med J 50:207-217.

Butler JM. 2015. The future of forensic DNA analysis. Philos Trans R Soc B Biol Sci 370:1-10.

Cox M. 1991. A study of the sensitivity and specificity of four presumptive tests for blood. J Forensic Sci36:1503-1511.

Flores S, Sun J, King J, Budowle B. 2014. Internal validation of the GlobalFiler ${ }^{\mathrm{TM}}$ Express PCR Amplification Kit for the direct amplification of reference DNA samples on a high-throughput automated workflow. Forensic Sci Int Genet 10:33-39.

Jobling MA, Gill P. 2004. Encoded evidence: DNA in forensic analysis. Nat Rev Genet 5:739-751.

Kayser M. 2015. Forensic DNA phenotyping: predicting human appearance from crime scene material for investigative purposes. Forensic Sci Int Genet 18:33-48.
Kemp BM, Smith DG. 2005. Use of bleach to eliminate contaminating DNA from the surface of bones and teeth. Forensic Sci Int 154:53-61.

Linacre A, Templeton JEL. 2014. Forensic DNA profiling: state of the art. Res Reports Forensic Med Sci 2014:425-36.

Mahajan KP, Parulekar VB, Lade SH, Malave MK. 2016. Crime Scene Forensic Evidence as Trace DNA Profiling Solves the Case. In Next Generation DNA Led Technologies. India: Forensic and Medical Bioinformatics.

Mcewen T, Regoeczi W. 2015. Forensic evidence in homicide investigations and prosecutions. J Forensic Sci 60:11881198.

Pickrahn I, Kreindl G, Müller E, Dunkelmann B, Zahrer W, Cemper-Kiesslich J, Neuhuber F. 2017. Contamination incidents in the pre-analytical phase of forensic DNA analysis in Austria-Statistics of 17 years. Forensic Sci Int Genet 31:12-18.

Quinones I, Daniel B. 2012. Cell free DNA as a component of forensic evidence recovered from touched surfaces. Forensic Sci Int Genet 6:26-30.

Seton C. 1988. Life For Sex Killer Who Sent Decoy to Take Genetic Text. UK: The Times.

Sorensen A, Berry C, Bruce D, Gahan ME, Hughes-Stamm S, McNevin D. 2016. Direct-to-PCR tissue preservation for DNA profiling. Int J Legal Med 130:607-613.

Walsh PS, Metzger DA, Higuchi R. 2013. Biotechniques $30^{\text {th }}$ anniversary gem Chelex 100 as medium for simple extraction of DNA for PCR-based typing from forensic material. Biotechniques 54:506-513.

Zwarenstein H. 1949. Orthotolidine hydrochloride test for blood in urine. J Clin Path 2:145-146. 